\title{
Growth evaluation and water relations of Erythrina velutina seedlings in response to drought stress
}

\author{
Elizamar Ciríaco da Silva ${ }^{1 *}$, Marcos F. A. Silva ${ }^{2}$, Rejane J. M. C. Nogueira ${ }^{3}$, \\ Manoel B. Albuquerque ${ }^{4}$.
}

\footnotetext{
${ }^{1}$ Centro de Ciências Biológicas e da Saúde, Departamento de Biologia, Universidade Federal de Sergipe, Sergipe, Brazil;

${ }^{2}$ Graduação em Engenharia Florestal, Universidade Federal Rural de Pernambuco, Pernambuco, Brazil.

${ }^{3}$ Departamento de Biologia, Universidade Federal Rural de Pernambuco, Pernambuco, Brazil.

${ }^{4}$ Departamento de Fitotecnia e Ciências Ambientais, Universidade Federal da Paraíba, Paraíba, Brazil.
}

* Corresponding author: Universidade Federal de Sergipe, Centro de Ciências Biológicas e da Saúde, Departamento de Biologia, Cidade Universitária Professor Aloísio de Campos, Av. Marechal Rondon, s/n, Jardim Rosa Elze, CEP 49100-000. Phone: +55 79 21056669. E-mail: elizaciriaco@gmail.com.

Received: 14 September 2010; Accepted: 12 December 2010

\begin{abstract}
Erythrina velutina Willd. (common name: mulungu) is a deciduous, heliophyte found in the semi-arid region of northeastern Brazil. To evaluate the growth and water relations of mulungu seedlings in soils with different degrees of moisture content, an experiment was carried out under greenhouse conditions using four water treatments (100\%, $75 \%, 50 \%$ and $25 \%$ of the field capacity- FC). Predawn $\left(\Psi_{\text {pdw }}\right)$ and midday leaf water potential $\left(\Psi_{\text {mdw }}\right)$, relative water content (RWC), plant height, number of leaves, stem diameter, leaf area $(L A)$, specific leaf area (SLA), leaf area ratio (LAR), dry matter in different organs, biomass partitioning and root:shoot ratio were evaluated. No differences were detected between treatments for $\Psi_{\text {pdw }}$ after 30 days; however, at midday, control plants and those under $75 \%$ FC underwent a greater reduction in $\Psi_{\text {mdw }}$ than plants cultivated with $50 \%$ and $25 \% \mathrm{FC}$. After 90 days, only the plants under $50 \%$ FC exhibited a reduction in $\Psi_{\text {mdw. }}$ RWC was reduced at midday, but there were no differences between treatments. Nearly all growth parameters were reduced due to water deficit, especially in the plants with $25 \% \mathrm{FC}$, as determined by the number of leaves, stem diameter, plant height, LA, SLA and dry mass in several organs. LAR and root:shoot ratio were not affected. Mulungu seedlings seem to have developed rusticity to overcome intermittent droughts with no change in the pattern of dry matter distribution. The maintenance of turgor pressure seems to be more associated to a reduction in the growth ratio than a reduction in leaf water potential.
\end{abstract}

Key words: biomass allocation, dry matter, leaf area, root to shoot ratio, relative water content, water potential

\section{RESUMO}

Erythrina velutina Willd. (comumente chamada mulungu) é uma espécie decídua, heliófita, encontrada nas regiões semi-áridas do Nordeste do Brasil. Com o objetivo de avaliar o crescimento e as relações hídricas de mudas de mulungu cultivadas em solo com diferentes graus de umidade, foi desenvolvido um experimento em condições de casa de vegetação utilizando quatro tratamentos hídricos (100\%, 75\%, 50\% e 25\% da capacidade de campo- CC). Foram avaliados o potencial hídrico foliar antes do amanhecer $\left(\Psi_{\text {pdw }}\right)$ e ao meio-dia ( $\left.\Psi_{\text {mdw }}\right)$, o teor relativo de água (TRA), altura das plantas, número de folhas, diâmetro do caule, área foliar (AF), 
área foliar específica (AFE), razão de área foliar (RAF), matéria seca para os diversos órgãos, partição de biomassa e relação raiz/ parte aérea. Não foram encontradas diferenças significativas para $\Psi_{\text {pdw }}$ após 30 dias; Entretanto, ao meio-dia, as plantas controle e aquelas sob 75\% CC sofreram uma maior redução no $\Psi_{\text {mdw }}$ do que as plantas cultivadas com 50\% e 25\% CC. Após 90 dias, apenas as plantas sob 50\% CC exibiram reduções no $\Psi_{\text {mdw. }} 0$ TRA foi reduzido ao meio-dia, mas não foram observadas diferenças entre oS tratamentos. 0 déficit hídrico reduziu quase todos os parâmetros de crescimento, especialmente nas plantas cultivadas com $25 \%$ CC, como observado para o número de folhas, diâmetro do caule, altura das plantas, AF, AFE e matéria seca para os diversos órgãos. A RAF e a razão raiz/parte aérea não foram afetadas. 0 mulungu na fase de muda parece ter desenvolvido rusticidade para superar períodos de seca, sem modificar o padrão de distribuição de matéria seca. A manutenção da pressão de turgescência parece estar mais associada a redução nas taxas de crescimento do que a redução do potencial hídrico foliar.

Palavras-chave: partição de biomassa, matéria seca, área foliar, razão raiz/parte aérea, teor relativo de água, potencial hídrico.

\section{INTRODUCTION}

Erythrina velutina Willd., commonly called mulungu in Brazil, is a plant species belonging to the family Fabaceae. The mulungu is a thorny tree with a height of eight to 12 meters that naturally occurs from the state of Ceará in northeastern Brazil to the states of Minas Gerais, Rio de Janeiro and São Paulo in southeastern Brazil (Lorenzi, 2002). However, it is also found in other countries, such as the Antilles, Venezuela, northern Colombia, Ecuador and Peru (Andrade Lima, 1989; Cardoso et al., 2008). This deciduous heliophyte inhabits in dry lands of semi-arid region of northeastern Brazil, the biome of which is commonly called Caatinga. The beautiful flowers of the mulungu are used in urban landscaping and its light, soft wood is used to make wooden shoes, toys, crates and rafts (Andrade Lima, 1989; Lorenzi, 2002; Cardoso et al., 2008).

The Caatinga biome is characterized by scarce, irregular rainfall ranging from 250 to $750 \mathrm{~mm}$ annually, with high luminosity and temperatures (Andrade Lima, 1989). Thus, plants living in the Caatinga often face water deficit throughout the year. Water deficit affects all aspects of growth and development and triggers physiological and morphological adaptations to the stressful environment (Silva et al., 2009b). Knowledge on these parameters is of fundamental importance to a better understanding of the establishment of plants and the ecosystem which they inhabit. Physiological studies enable the understanding of how these species modify their phenotype in response to variations in the environmental conditions, which can often be inhospitable (Leal et al., 2005).

Arid conditions generally exclude the establishment of trees, as periodic drought reduces their survival rate. Plants transplanted to the field undergo severe physiological shock due to the decreased capacity for water absorption. The roots do not grow fast enough to absorb sufficient water to compensate for the loss of water in the leaves through transpiration (Kozlowski and Pallardy, 2002). This causes a loss of turgor pressure. Water availability is undoubtedly the main factor affecting plant growth and development. Moreover, high luminosity, high temperatures and low air relative humidity are further problems plants face in dry lands.

Although the general growth of organs is genetically defined, environmental conditions can strongly modify this pattern (Walter and Schurr, 2005). Growth analysis is an explanatory way to interpret plant form and function and serves in the assessment of the inner processes as well as the plant as a whole (Hunt et al., 2002). Plants growing in poor sites (dry or low in nutrients) allocate a greater proportion of photosynthates to the roots in comparison to plants growing in sites with adequate water and/or nutrient availability (Kozlowski and Pallardy, 2002). This phenomenon induces changes in the distribution of dry matter in roots as well as an increase in the root to shoot ratio, as found for Myracrodruon urundeuva (Allemão) Engl. (Figueirôa et al., 2004), Prosopis argentina Burkart and Prosopis alpataco Phil (Villagra and Cavagnaro, 2006). Drought strongly reduces leaf area (Bañon et al., 2004; Pagter et al., 2005), the number of leaves (falling or the emission of new leaves), plant height (Rajendrudu et al., 1999; Figueirôa et al., 2004; Villagra and Cavagnaro, 2006) and dry matter (Bañon et al., 2004; Figueirôa et al., 2004), which affects final productivity.

When there is a reduction in the moisture content in the soil, there is a subsequent reduction in water influx in the cells, which typically lose the turgor pressure necessary for leaf expansion and root elongation (Sadras and Milroy, 1996; 
Taiz and Zeiger, 2004). When the water absorbed by the roots is insufficient to compensate for the moisture lost through transpiration, there is a decrease in leaf water potential (Silva et al., 2009). This phenomenon can occur due to the architecture of the roots (Steudle and Peterson, 1998), low water availability in dry soils or both.

Plants capable of surviving and producing under conditions of low water availability are considered drought tolerant. From an eco-physiological standpoint regarding, the strategy for plants living in a stressed environment is not the maximization of productivity, but the establishment of a balance between yield and survival (Larcher, 2006), whereas, from an agronomic standpoint, yield is the main objective. Plants that stop growth in order to survive in a stressful environment could be considered tolerant, but such plants produce fewer grains, leaves or fruit, which reduces their economic worth (DaMatta, 2004).

Knowledge on the physiological traits of native plants living in stressed environments is important to gaining a better understanding of stress tolerance. Thus, the aim of present study was to evaluate growth parameters and water relations in mulungu seedlings under different levels of water deficit to test the hypothesis that mulungu seedlings tolerate drought by changing organ growth patterns, altering the root to shoot ratio and decreasing the leaf water potential without diminishing the relative water content (thereby maintaining turgor pressure).

\section{MATERIALS AND METHODS}

The experiment was carried out under greenhouse conditions at the Laboratory of Plant Physiology of the Biology Department of the Universidade Federal Rural de Pernambuco (UFRPE), Brazil, from April to July 2008. Seedlings were obtained from seeds collected from trees in the Fazenda Nova city, which is located in the semi-arid region of the state of Pernambuco, Brazil. The seeds were sown in trays containing washed sand watered daily. Thirty days following emergence, selected seedlings with two pairs of leaves were transplanted to pots with $5 \mathrm{~kg}$ of soil from the Garanhuns city (Pernambuco, Brazil) (8053'25" S, $36^{\circ} 29^{\prime} 34^{\prime \prime}(\mathrm{W})$.

The physical and chemical soil analyses were performed at the Laboratory of Soil Fertility and Laboratory of Soil Physics, Agronomy Department/UFRPE. The following were the physical characteristics of the soil: sandy-loam texture, composed of
$79 \%$ sand, $7 \%$ clay and $14 \%$ silt; $8.48 \%$ soil moisture at field capacity ( $0.3 \mathrm{~atm})$; and the $3.48 \%$ wilting point (15 atm). The following was the soil chemical characterization: $30 \mathrm{mg} / \mathrm{dm}^{3}$ of $\mathrm{P}, 0.46 \mathrm{cmol} / \mathrm{dm}^{3}$ of $\mathrm{Na}^{+}, 0.29 \mathrm{cmol}_{d} / \mathrm{dm}^{3}$ of $\mathrm{K}^{+}, 4.00 \mathrm{cmol} /$ $\mathrm{dm}^{3}$ of $\mathrm{Ca}^{2+}+\mathrm{Mg}^{2+}, 2.50 \mathrm{cmol}_{d} / \mathrm{dm}^{3}$ of $\mathrm{Ca}^{2+}, 0.20 \mathrm{cmol}_{d} /$ $\mathrm{dm}^{3}$ of $\mathrm{Al}^{3+}, 4.19 \mathrm{cmol} / \mathrm{dm}^{3}$ of $\mathrm{H}+\mathrm{Al}, 32.9 \mathrm{~g} / \mathrm{kg}$ of organic matter and pH 5.3 .

After 15 days of acclimatization under daily irrigation at nearly field capacity, the seedlings were submitted to different water treatments. A completely randomized design was used with four water treatments $(100,75,50$ and $25 \%$ of field capacity), with eight replicates each. Field capacity (FC) was determined following the gravimetric method described by Souza et al. (2000).

Water relations were evaluated through predawn and midday leaf water potential ( $\Psi_{\text {pdw }}$ and $\Psi_{\text {mdw }}$, respectively) after 30,60 and 90 days and relative water content (RWC) was determined after 30 and 90 days, using leaves located in the middle of the main branch of each plant. After harvest, the leaves were wrapped up in plastic film, cut, placed in a chest with ice and sent to the laboratory. Leaf water potential was determined using a pressure chamber (model 3035, Soil Moisture Equipment Corp, Santa Barbara, CA, USA) (Scholander et al., 1965). The same leaves were used to determine the RWC, which was calculated following the method described by Cairo (1995), using the following equation: $\mathrm{RWC}=(\mathrm{FMW}-\mathrm{DMW}) / \mathrm{SMW}-\mathrm{DMW})$ $\times 100$, in which FMW is fresh matter weight, DMW is dry matter weight and SMW is saturated matter weight.

Growth analysis was performed by determining plant height, the number of leaves and stem diameter weekly. An allometric equation was used to determine the leaf area based on the correlation of leaf area (LA) with the length $(L)$ and width (W) of a hundred mature $E$. velutina leaves [ $L A=0.247$ $\left.(L \times W)-5.223\left(r^{2}=0.98\right)\right]$. Thus, the total leaf area of each replicate was obtained by the sum of all leaves on the $30^{\text {th }}$ and $90^{\text {th }}$ days of water treatment.

The dry matter of the leaf, stem and root was determined after 90 days of treatment. For such, the organs were harvested and placed in an oven at $65^{\circ} \mathrm{C}$ until reaching a constant weight. Biomass partitioning was calculated for the organs. The root:shoot ratio was calculated using dry matter data expressed in percentage (\%), following the method described by Benincasa (2003). 
During the experimental period, air temperature in the greenhouse ranged from $26.8^{\circ} \mathrm{C}$ to $33.8^{\circ} \mathrm{C}$, relative humidity ranged from $44.4 \%$ to $66 \%$ and the photosynthetically active radiation ranged from $34 \mathrm{mmol} . \mathrm{m}^{-2} . \mathrm{s}^{-1}$ to $1350 \mathrm{mmol} \cdot \mathrm{m}^{-2} . \mathrm{s}^{-1}$ (at the end of the day and at midday, respectively).

To normalize the values for the number of leaves, the data were converted using $\sqrt{ } x+0.5$ prior to analysis, but the real means are shown in the results. The data were submitted to analysis of variance (ANOVA). When significant differences were detected, the means were compared using Tukey's multiple range test $(P<0.05)$.

\section{RESULTS}

Water relations in the mulungu seedlings were slightly affected by water deficit. After 30 days under water deficit, no reduction in predawn leaf water potential was found (Table 1). However, at midday, control plants and those under $75 \% \mathrm{FC}$ underwent a greater reduction in $\Psi_{\text {mdw }}$ than plants cultivated with $50 \%$ and $25 \%$ FC. After 60 and 90 days of water deficit, no significant difference in $\Psi_{\text {pdw }}$ was detected between treatments and, at midday, only plants under 50\% FC exhibited a lower leaf water potential after 90 days (Table 1).

Table 1. Predawn ( $\left.\Psi_{\text {pdw }}\right)$ and at midday $\left(\Psi_{\text {mdw }}\right)$ leaf water potential in mulungu seedlings (Erythrina velutina) cultivated in greenhouse condition under different soil moisture content at 30,60 and 90 days after treatments.

\begin{tabular}{cccc}
\hline Water treatments (Field capacity) & 30 days & 60 days & 90 days \\
\hline & \multicolumn{3}{c}{$\Psi_{\text {pdw }}$} \\
\cline { 2 - 4 } $100 \%$ & $-0.07 \mathrm{Aa}$ & $-0.09 \mathrm{Aa}$ & $-0.10 \mathrm{Aa}$ \\
$75 \%$ & $-0.12 \mathrm{Aa}$ & $-0.12 \mathrm{Aa}$ & $-0.07 \mathrm{Aa}$ \\
$50 \%$ & $-0.17 \mathrm{Aa}$ & $-0.17 \mathrm{Aa}$ & $-0.11 \mathrm{Aa}$ \\
$25 \%$ & $-0.20 \mathrm{Aa}$ & $-0.31 \mathrm{Aa}$ & $-0.13 \mathrm{Aa}$ \\
\hline & \multicolumn{3}{c}{$\Psi_{\text {mdw }}$} \\
\hline $100 \%$ & $-0.86 \mathrm{Cb}$ & $-0.85 \mathrm{Ab}$ & $-0.41 \mathrm{Ab}$ \\
$75 \%$ & $-0,78 \mathrm{BCb}$ & $-0.74 \mathrm{Ab}$ & $-0.48 \mathrm{ABb}$ \\
$50 \%$ & $-0,56 \mathrm{Bb}$ & $-0.86 \mathrm{Ab}$ & $-0.63 \mathrm{Bb}$ \\
$25 \%$ & $-0.18 \mathrm{Aa}$ & $-0.89 \mathrm{Ab}$ & $-0.52 \mathrm{ABb}$ \\
\hline
\end{tabular}

Means followed by different letters (upper case among treatments and lower case between hour of evaluation) significantly differ by Tukey's multiple range test $(P<0.05)$.

RWC in the mulungu seedlings did not differ significantly between treatments or evaluation times after 30 days (Figure 1). After 90 days, RWC was lower at midday than at predawn, but there were no significant differences between treatments.

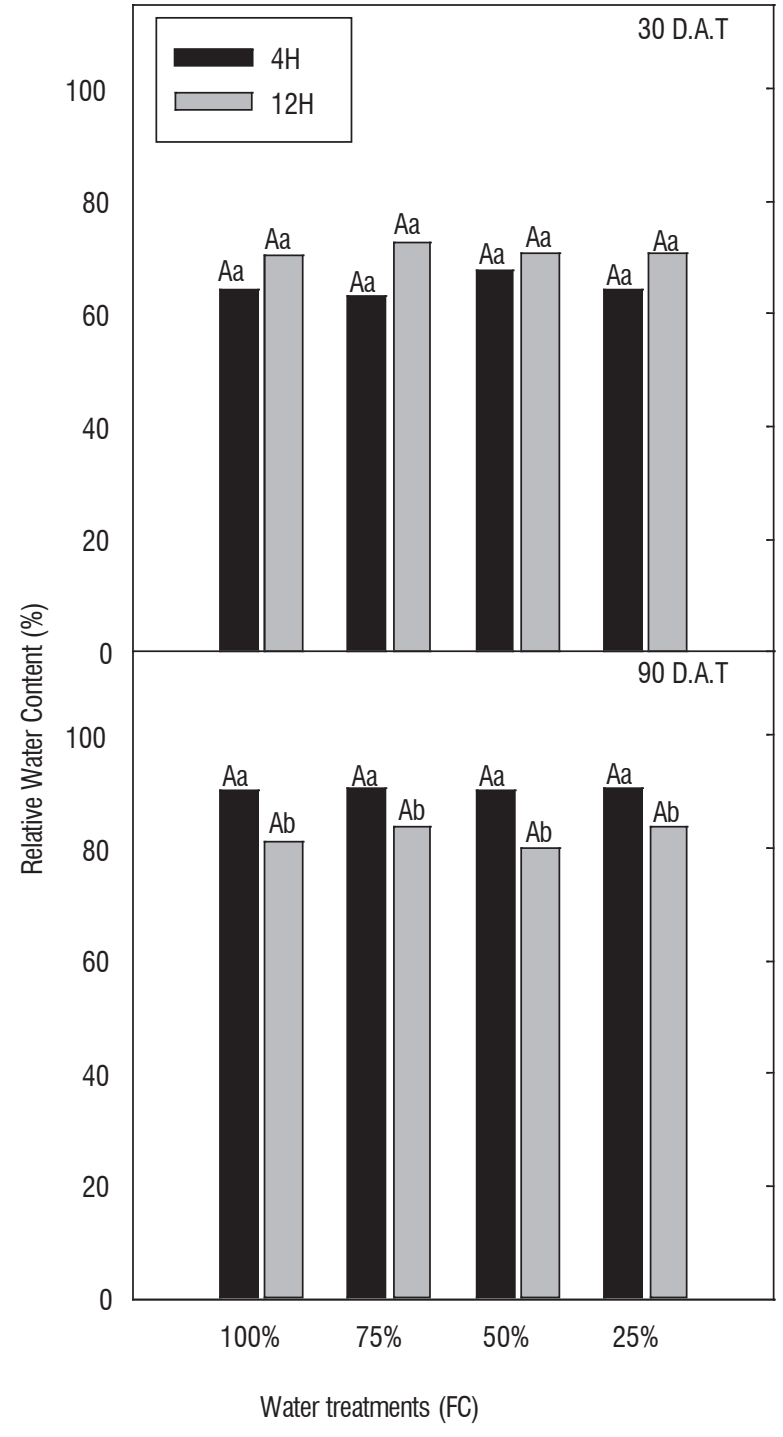

Figure 1. Predawn (4h) and at midday (12 h) relative water content (RWC) in mulungu seedlings (Erythrina velutina) cultivated in greenhouse condition under different soil moisture content at 30 and 90 days after treatments (DAT). Means followed by different letters (upper case among treatments and lower case between hours of evaluation) significantly differ by Tukey's multiple range test $(P<0.05)$.

Seedling growth decreased with the reduction in the moisture content in the soil. After 15 days of treatment, there was a reduction in the number of leaves on plants grown with 25\% FC in comparison to those grown with 100\% FC (Figure 2). Stem diameter and plant height began to reduce after 21 days of treatment (Figure 2). At the end of the experimental period, these reductions among the plants grown with $50 \%$ and $25 \%$ FC were approximately $20 \%$ and $50 \%$ for the number of leaves, $22 \%$ and $56 \%$ for stem diameter 
and $37 \%$ and $64 \%$ for plant height, respectively. Drought conditions did not restrain the emission of new leaves during the experimental period. However, stem diameter and plant height were more sensitive to severe stress ( $25 \% \mathrm{FC})$, with growth arrest in length and width at the beginning of the stress period (Figure 2).

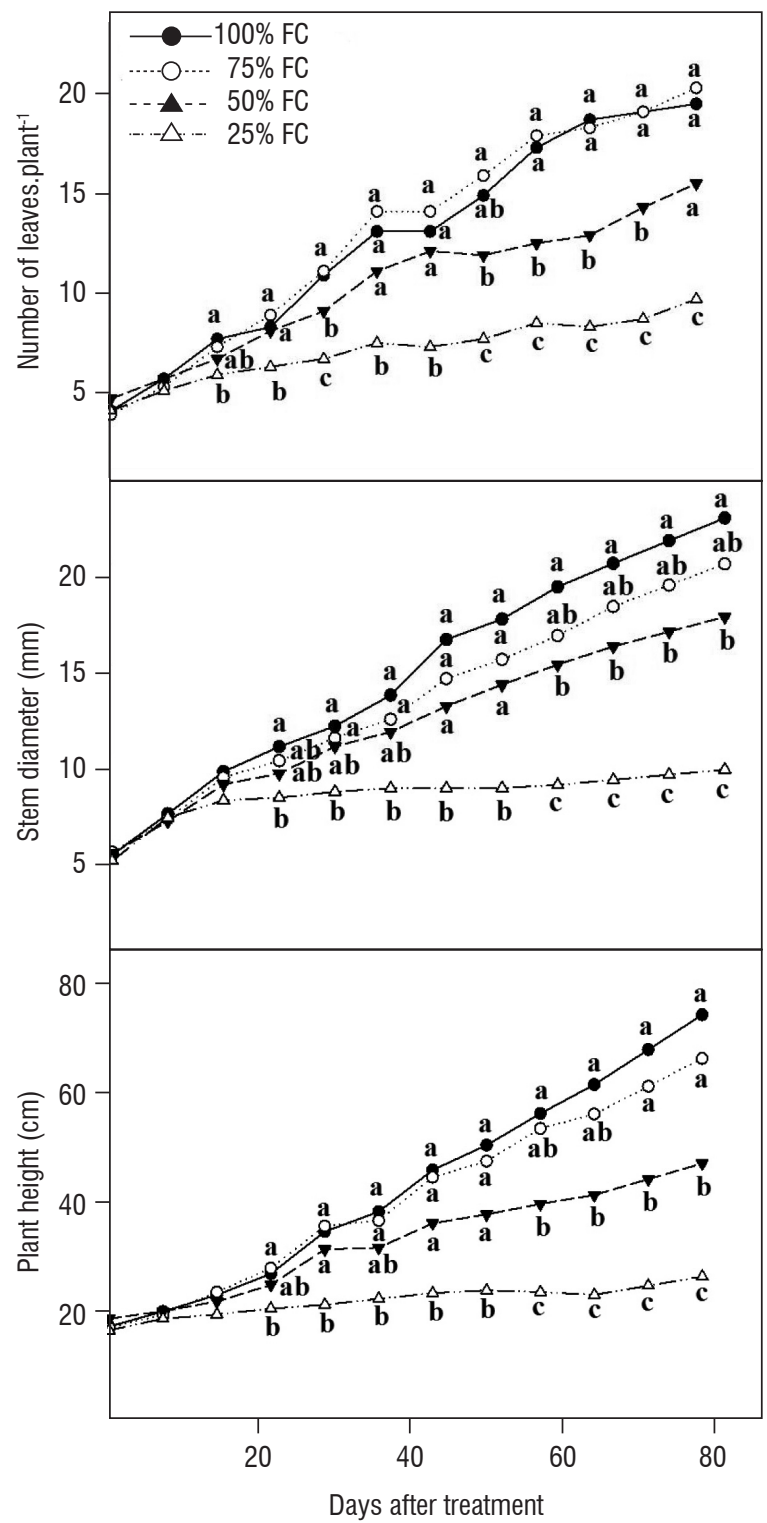

Figure 2. Number of leaves, stem diameter and plant height of mulungu seedlings (Erythrina velutina) grown in greenhouse under different soil moisture content. Means followed by different letters significantly differ among treatments by Tukey's multiple range test $(P<0.05)$.

Leaf area decreased in all water stress treatments at 30 and 90 days of evaluation (Figure 3 ). After 90 days of treatment, the stress significantly decreased leaf area at a proportion of approximately $22 \%, 60 \%$ and $91 \%$ among plants submitted to 75 , 50 and $25 \% \mathrm{FC}$, respectively. Water deficit did not significantly affect the leaf area ratio $(P<0.05)$. However, specific leaf area increased significantly $(P<0.05)$ in plants submitted to $25 \% \mathrm{FC}$ in comparison to the control plants and those under $50 \%$ FC (Table 2).

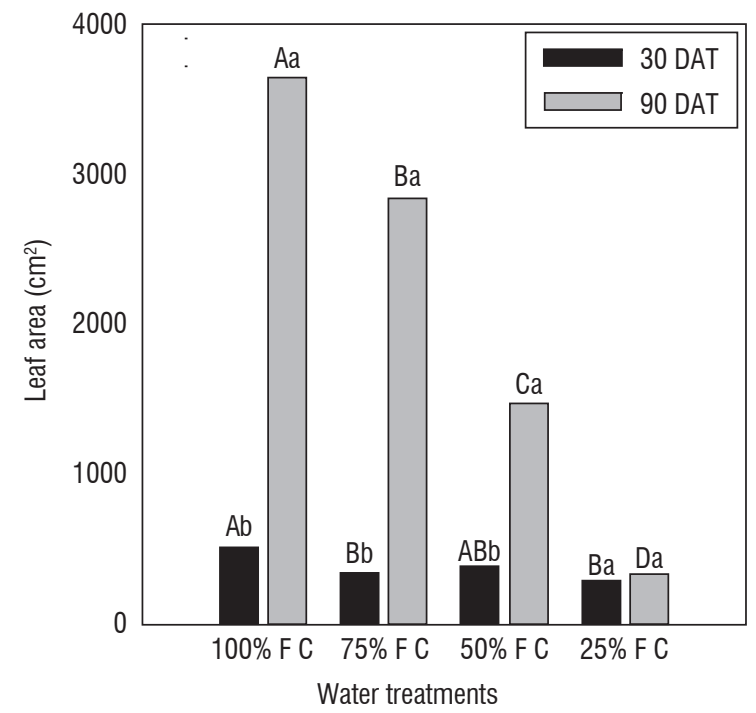

Figure 3. Leaf area of mulungu seedlings (Erythrina velutina) grown in greenhouse conditions under different soil moisture content after 30 and 90 days of treatment (DAT). Means followed by the same letters, upper case among treatments and lower case between days of evaluation do not significantly differ by Tukey's multiple range test $(P<0.05)$.

Table 2. Leaf area ratio (LAR) and specific leaf area (SLA) of mulungu seedlings (Erythrina velutina) grown in greenhouse after 90 days under different soil moisture content.

\begin{tabular}{ccc}
\hline Treatments & LAR $\left(\mathrm{cm}^{2} \cdot \mathrm{g}^{-1} \mathrm{TDW}\right)$ & $\mathrm{SLA}\left(\mathrm{cm}^{2} \cdot \mathrm{g}^{-1} \mathrm{LDW}\right)$ \\
\hline $100 \% \mathrm{FC}$ & $80.30 \mathrm{a}$ & $284.16 \mathrm{~b}$ \\
$75 \% \mathrm{FC}$ & $86.30 \mathrm{a}$ & $317.30 \mathrm{ab}$ \\
$50 \% \mathrm{FC}$ & $74.83 \mathrm{a}$ & $272.91 \mathrm{~b}$ \\
$25 \% \mathrm{FC}$ & $82.73 \mathrm{a}$ & $451.28 \mathrm{a}$ \\
\hline
\end{tabular}

Means followed by the same letters among treatments do not significantly differ by Tukey's multiple range test $(P<0.05)$. TDW $=$ total dry matter weight. LDW $=$ Leaf dry matter weight.

Dry matter in the leaf, stem, root and total dry matter was significantly reduced by water stress in plants cultivated with 50 and 25\% FC (Figures 4 and 5). This reduction among plants submitted to $25 \% \mathrm{FC}$ was $94 \%, 88 \%, 88 \%$ and $90 \%$ for the leaf, stem, roots and total dry matter, respectively. However, the dry matter distribution pattern was not affected by water deficit. Moreover, the root:shoot ratio did not differ significantly between 
treatments (Figure 5). Although total dry matter was significantly reduced, biomass partitioning was not affected by drought (Table 3). The plants distributed photosynthates in such a way as to allow the same extent of organ growth regardless of soil moisture conditions. Thus, most photosynthates were allocated to producing the stem $(46 \%)$, whereas $24 \%$ were allocated to the leaves and $30 \%$ to the roots (Table 3 ).

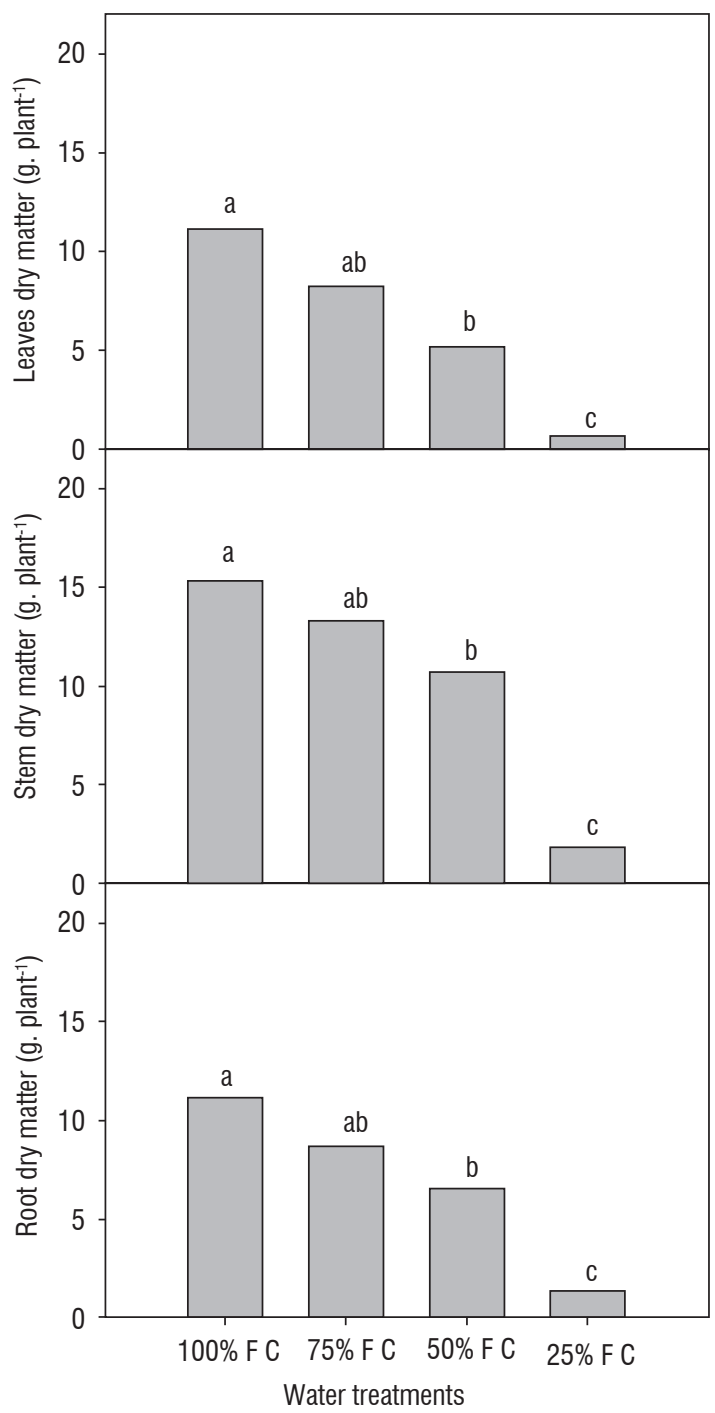

Figure 4. Leaf, stem and root dry matter of mulungu seedlings (Erythrina velutina) grown in greenhouse under different soil moisture content. Means followed by different letters significantly differ by Tukey's multiple range test $(P<0.05)$.

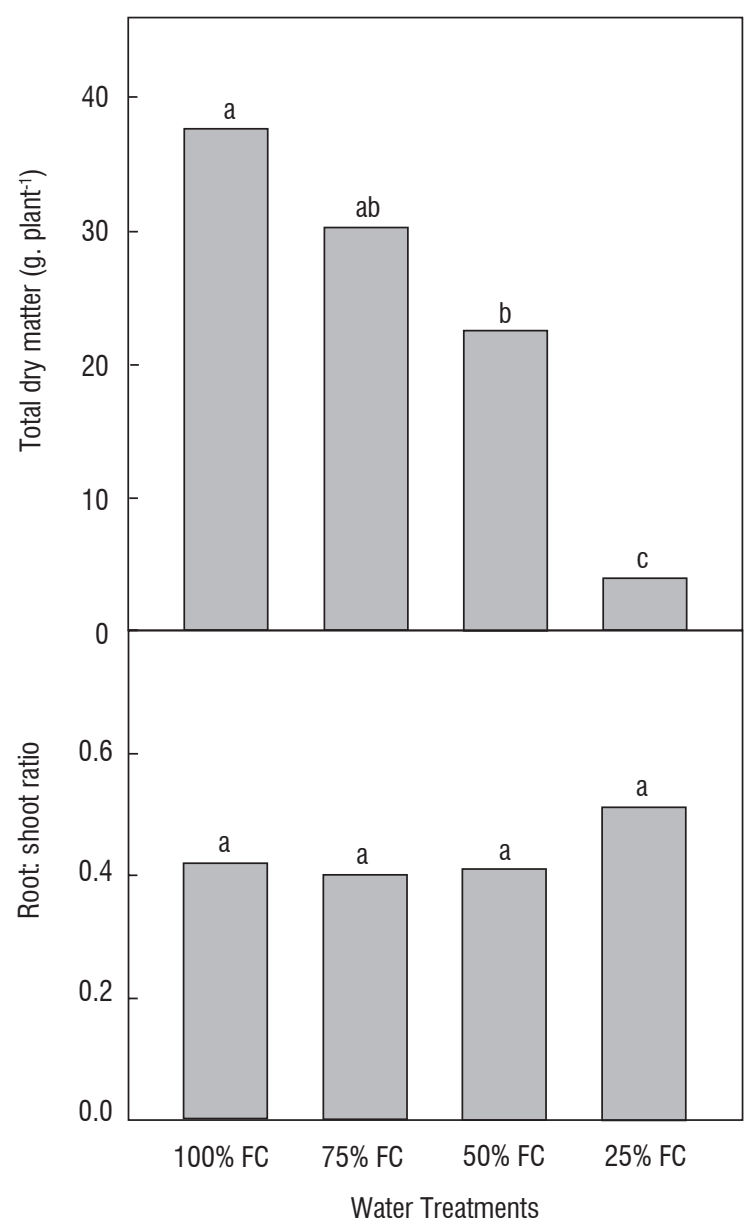

Figure 5. Total dry matter and root to shoot ratio of mulungu seedlings (Erythrina velutina) grown in greenhouse under different soil moisture content. Means followed by different letters significantly differ by Tukey's multiple range test $(P<0.05)$

Table 3. Biomass partitioning to leaves (BPL), stem (BPS), and roots (BPR) (in the basis of mass) of mulungu seedlings (Erythrina velutina) grown in greenhouse under different soil moisture content.

\begin{tabular}{cccc}
\hline Treatments & BPL (\%) & BPS (\%) & BPR (\%) \\
\hline $100 \% F C$ & $29.7 \mathrm{a}$ & $40.7 \mathrm{a}$ & $29.6 \mathrm{a}$ \\
$75 \% \mathrm{FC}$ & $27.3 \mathrm{a}$ & $44.1 \mathrm{a}$ & $28.6 \mathrm{a}$ \\
$50 \% \mathrm{FC}$ & $23.9 \mathrm{a}$ & $47.4 \mathrm{a}$ & $28.7 \mathrm{a}$ \\
$25 \% \mathrm{~b} \mathrm{FC}$ & $16.4 \mathrm{a}$ & $50.4 \mathrm{a}$ & $33.2 \mathrm{a}$ \\
\hline Mean & 24.3 & 45.7 & 30.0 \\
\hline
\end{tabular}

Means followed by different letters significantly differ by Tukey's multiple range test $(P<0.05)$. 


\section{DISCUSSION}

It is well known that leaf water potential is often reduced with a decrease in water availability in the soil. In the present study, there was no significant reduction in the predawn leaf water potential in mulungu plants during the stress period (Table 1). At midday, however, control plants and those submitted to $75 \%$ and $50 \% \mathrm{FC}$ underwent a greater reduction in $\Psi_{\text {mdw }}$ than those cultivated with $25 \% \mathrm{FC}$. This finding may be explained by the excessive loss of water through transpiration at midday among the control plants and the insubstantial reduction in stomatal opening among the plants submitted to $75 \% \mathrm{FC}$ and $50 \% \mathrm{FC}$ (unpublished data). When plants have water enough to maintain stomata open, the water loss rate in high evaporative hours is greater than the absorption rate in the roots, which leads to the depletion of water content in the leaf tissue. Many plants in dry areas partially close their stomata at times of higher evaporative demand when exposed to water deficit (Silva et al., 2003; Silva et al., 2009a). In the daily course of gas exchange after 64 days of treatment, midday transpiration (E) values among mulungu control plants were approximately $8 \mathrm{mmol} \cdot \mathrm{m}^{-2} \cdot \mathrm{s}^{-1}$, but less than $1 \mathrm{mmol} \cdot \mathrm{m}^{-2} \cdot \mathrm{s}^{-1}$ among stressed plants (25\% FC) (unpublished data). The fact that there were no significant differences between treatments with regard to predawn leaf water potential demonstrates the efficient recovery of this plant when stomata is closed overnight.

After 60 and 90 days of stress, the lowest $\Psi_{\text {mdw }}$ values occurred in the plants under mild stress $(50 \% \mathrm{FC})$ rather than those under severe stress (25\% FC). These findings may at least partially be explained by the shorter height of the plants submitted to $25 \%$ FC $(25.9 \mathrm{~cm})$, which was approximately $65 \%$ less than that of the control plants $(73 \mathrm{~cm})$ (Figure 2), and the reduction in both the number of leaves and leaf area responsible for transpiration, thereby helping the stressed plants maintain their water status. The water absorption rate and rise into the xylem depends on plant height, xylem water tension and transpiration rate in the leaves. Cell turgor pressure in the leaves depends on both the influx of water available in the soil and the solutes in the leaf cells responsible for reducing the osmotic potential and maintaining water within the cell. Thus, the reduced water availability to the plants submitted to $25 \%$ FC led to a slow growth rate and the shorter height allowed the maintenance of water status in these plants.

The extension of the stress period seems to induce hardening (rusticity) in stressed plants (Kozlowski and Pallardy,
2002). The results regarding the RWC demonstrate also that mulungu seedlings maintained adequate water content within the cells even under conditions of low water availability (25\% FC). Although the accumulation of organic solutes was not evaluated in the present study, the fact that there were no significant reductions in $\Psi_{w}$ or RWC suggests that osmotic adjustment is not the mechanism the mulungu uses to maintain water status when cultivated under conditions of water deficit. Instead, reduced growth is the strategy employed to better maintain water status.

Drought reduced all aspects of growth in the mulungu plants. Less than $50 \% \mathrm{FC}$ significantly $(P<0.05)$ and negatively affected growth, reducing the number of leaves, stem diameter, plant height, dry matter and leaf area (Figures 1, 2, 3 and 4). Growth maintenance depends on the turgor pressure for cell expansion and division, which is affected by drought (Sadras and Milroy, 1996; Taiz and Zeiger, 2004). Thus, a reduction in growth is considered the principal effect of drought in plants (Larcher, 2006). Severe stress (as observed in the plants cultivated with $25 \% \mathrm{FC}$ ) impeded the turgor pressure from causing cell expansion. Morphological and biochemical changes in plants under water deficit lead to acclimation, subsequent functional damage and the loss of plant parts as water stress becomes more severe (Chaves et al., 2003; Costa e Silva et al., 2004), resulting first in a slower growth rate (acclimation phase). This occurs due to the inhibition of cell expansion and reduction in carbon assimilation (Costa e Silva et al., 2004). Mulungu plants under severe stress emitted a lower number of new leaves in comparison with those under mild stress and the control plants. However, since no falling of leaves was observed throughout the experiment and taking into account that adequate cellular water content was maintained even under severe stress, the growth arrest of mulungu seedlings must represent an adaptative response rather than a deleterious effect as consequence of drought.

Native plants from arid and semi-arid environments exhibit a better performance when cultivated with sufficient water, as observed in Tabebuia aurea (Manso) Benth. \& Hook. f. ex S. Moore (Cabral et al., 2004) and Myracrodruon urundeuva Allemão (Figueirôa et al., 2004). A reduction in growth as a consequence of a decrease in turgor pressure allows adapted plants to survive under conditions of less water availability, as small plants have fewer leaves and a smaller leaf area (less transpiration area and better water management). 
As a consequence of stomatal closure, dry matter production is also reduced due to low carbon assimilation. Gas exchange was not evaluated in the present paper, but after 64 days of stress the transpiration rate was fourfold to fivefold less than that in the control plants (unpublished data). Reduced water availability (25\% FC) induced reductions in the stomatal aperture, thereby reducing carbon gains and dry matter production. However, the fact that the RWC was not reduced suggests that some chemical signal, such as ABA, could be acting to promote stomatal closure. A number of studies have shown reductions in the dry matter of plants submitted to water deficit, as observed for Tabebuia aurea seedlings (Cabral et al., 2004) and Myracrodum urundeuva (Figueirôa et al., 2004), which are native trees from the Caatinga biome in Brazil, and Prosopis alpataco and Prosopis argentina (Villagra and Cavagnaro, 2006), which are native shrubs from dry lands in Argentina.

Severe water deficit in the soil generally induces changes in the pattern of dry matter distribution, increasing the root in relation to shoot growth (Atkinson et al., 1999). However, this was not observed in the present study on mulungu seedlings, although, in absolute number, there was a tendency toward increasing the root to shoot ratio in plants submitted to $25 \%$ FC. This change has been reported in Prosopis argentina and Prosopis alpataco under conditions of water deficit (Villagra and Cavagnaro, 2006) and is recognized as a adaptive strategy for exploring greater depths in the soil.

The development of smaller leaves in plants growing in a water-deficient environment as well as the lower number of leaves and smaller specific leaf area are aspects that characterize xeromorphism (Larcher, 2006; Villagra and Cavagnaro, 2006). The leaf area ratio, which is a morphological and physiological parameter that expresses the leaf area useful to growth, is the area used for photosynthesis (LA/TDM), whereas specific leaf area is related to leaf surface and expresses the exportation or retention of photosynthates (LA/LDM) (Benincasa, 2003). Thus, plants capable of producing $1 \mathrm{~g}$ of dry matter with a smaller leaf area exhibit more efficient water use (Silva and Nogueira, 2003), once dry matter represents carbon assimilation. The mulungu control plants required approximately $80 \mathrm{~cm}^{2}$ to produce $1 \mathrm{~g}$ of dry matter and the plants submitted to $25 \% \mathrm{FC}$ required a statistically equal 83 $\mathrm{cm}^{2}$ (Table 1). This finding demonstrates that, under conditions of water deficit, mulungu seedlings use the same leaf area to produce the same amount of dry matter. This may at least partially mean that the reduction in leaf area as a response to water deficit led to a reduction in the production of dry matter, as the plants did not demonstrate efficiency by using a smaller area to produce the same amount of dry matter. Thus, in the present experiment, water deficit did not induce greater efficiency regarding water use in mulungu seedlings in the initial growth stage. Moreover, specific leaf area increased under severe water deficit from 284.16 to $451.84 \mathrm{~cm}^{-2} \cdot \mathrm{g}^{-1} \mathrm{LDM}$ (Table 1). Specific leaf area was expected to be reduced as a xeromorphic characteristic, thereby increasing the thickness of the leaf, but this did not occur.

Desiccation can be postponed by all mechanisms that enable plants to maintain favorable water content in the tissues for a greater length of time, despite water deficits in the soil and atmosphere. One such mechanism is the development of an extensive root system, which reaches deeper depths in soil containing water (Larcher, 2006). In the present study, no changes in root:shoot ratio were observed, demonstrating that this species distributed carbon assimilation similarly under water deficit and situations of adequate water availability; although, in absolute values, there was a tendency toward greater root growth (Figure 4).

Plants adapted to drought conditions tend to undergo changes in some physiological traits in order to better manage water. Mulungu seedlings seem to have developed rusticity in order to adapt to stress conditions. Although adapted to semiarid conditions as a native plant of the Caatinga (dry lands of northeastern Brazil), the present study demonstrates that mulungu seedlings perform better when cultivated with an adequate water supply in the initial growth phase. Under conditions of water deficit, these plants developed rusticity to overcome water stress. Survival in the initial developmental phase was not achieved by a change in the growth pattern (root:shoot ratio), and a reduction in leaf water potential without diminishing relative water content (indication of osmotic adjustment) as it was hypothesized, but by reduction in water loss by reducing organ growth and probably also of its metabolism in order to better manage the low water availability in the soil. This suggests that mulungu plants tolerate drought with high water potential in the tissues and the development of xeromorphic characteristics for the conservative use of water through different morphological adaptations.

Acknowledgements: The authors would like to thank biologist Danubia Ramos and MSc. Hugo Henrique Costa do Nascimento from the Laboratory of Plant Phisiology/UFRPE for their assistance and the Laboratory of Soil Fertility and Laboratory of Soil Physics, Department of Agronomy/UFRPE, for the soil analysis. 


\section{REFERENCES}

Andrade Lima D (1989) Plantas das Caatingas. Academia Brasileira de Ciências, Rio de Janeiro.

Atkinson CJ, Policarpo M, Webster AD, Kuden AM (1999) Drought tolerance of apple rootstocks: production and partitioning of dry matter. Plant Soil 206:223-235

Bañon S, Fernandez, JA, Franco JA., Torrecillas A, Alarcón JJ, Sánchez-Blanco $\mathrm{M} \mathrm{J}$ (2004) Effects of water stress and night temperature preconditioning on water relations and morphological and anatomical changes of Lotus creticus plants. Sci. Hort. 101:333-342.

Benincasa MMP (2003) Análise de crescimento de plantas. $2^{\text {nd }}$ ed. Funep, Jaboticabal.

Cabral, EL, Barbosa DCA, Simabukuro EA (2004) Crescimento de plantas jovens de Tabebuia áurea (Manso) Benth. \& Hook. f. ex. S. Moore submetidas a estresse hídrico. Acta Bot. Bras. 18: 241-251.

Cairo PAE (1995) Curso básico de relações hídricas de plantas. UESB, Vitória da Conquista.

Cardoso EA, Alves EU, Bruno RLA, Alves AU, Alves AU, Silva KB (2008) Emergência de plântulas de Erythrina velutina em diferentes posições e profundidades de semeadura. Ciência Rural 38:2618-2621.

Chaves MM, Maroco JP, Pereira JS (2003) Understanding plant response to drought - from genes to the whole plant. Funct. Plant. Biol. 30:1-26.

Costa e Silva F, Shvaleva A, Maroco JP, Almeida MH, Chaves, MM, Pereira JS (2004) Responses to water stress in two Eucalyptus globulus clones differing in drought tolerance. Tree Physiol. 24:1165-1172.

DaMatta FM (2004) Exploring drought tolerance in coffee: a physiological approach with some insights for plant breeding. Braz. J. Plant Physiol. 16:1-6.

Figueirôa JM, Barbosa DCA, Simabukuro EA (2004) Crescimento de plantas jovens de Myracrodruon urundeuva Allemão (Anacardiaceae) sob diferentes regimes hídricos. Acta Bot. Bras. 18: 573-580.

Hunt R, Causton DR, Shipley B, Askew AP (2002) A modern tool for classical plant growth analysis. Ann. Bot. 90:485-488.

Kozlowski TT, Pallardy SG (2002) Acclimation and Adaptive Responses of Woody Plants to Environmental Stresses. Bot. Rev. 68:270.334.

Larcher W (2006) Ecofisiologia Vegetal. Rima, São Carlos.

Leal IR, Silva JMC, Tabarelli M, Larcher Jr TE (2005) Mudando o curso da conservação da biodiversidade na Caatinga do Nordeste do Brasil. Megadiversidade. 1: 139-146
Lorenzi H (2002) Árvores brasileiras: manual de identificação e cultivo de plantas arbóreas do Brasil, v.1, $4^{\text {th }}$ ed. Instituto Plantarum, Nova Odessa.

Pagter M, Bragato C, Brix H (2005) Tolerance and physiological responses of Phragmites australis to water deficit. Aquatic Bot. 81:285-299.

Rajendrudu G, Naidu CV, Mallikarjuna K (1999) Effect of water stress on photosynthesis and growth in two teak phenotypes. Photosynthetica. 3:627-630.

Sadras VO, Milroy SP (1996) Soil-water thresholds for the responses of leaf expansion and gas exchange: a review. Field Crop Res. 47:253-266.

Scholander PF, Hammel HT, Bradstreet ED, Hemmingsen EA (1965) Sap pressure in vascular plants. Negative hydrostatic pressure can be measured in plants. Sci. 148:339-346.

Silva EC, Nogueira RJMC (2003) Crescimento de quatro espécies lenhosas cultivadas sob estresse hídrico em casa de vegetação. Rev. Ceres. 50:203-217.

Silva EC, Nogueira RJMC, Vale FHA, Araújo FP, Pimenta MA (2009a) Stomatal changes induced by intermitente drought in four umbu tree genotypes. Braz. J. Plant Physiol. 21:33-42.

Silva EC, Nogueira RJMC, Vale FHA, Melo NF, Araújo FP (2009b) Water relations and organic solutes production in four umbu (Spondias tuberosa) tree genotypes under intermittent drought. Braz. J. Plant Physiol. 21:43-53.

Silva EC, Nogueira RJMC, Azevedo Neto AD, Santos VF (2003) Comportamento estomático e potencial da água da folha em três espécies lenhosas cultivadas sob estresse hídrico. Acta Bot. Bras. 17: 231-246.

Souza CC, Oliveira FA, Silva IF, Amorim Neto MS (2000) Avaliação de métodos de determinação de água disponível e manejo da irrigação em terra roxa sob cultivo de algodoeiro herbáceo. R. Bras. Eng. Agríc. Ambiental. 4:338-342.

Steudle E, Peterson C A (1998) How does water get through roots? J. Exp. Bot. 49:775-788

Taiz L, Zeiger E (2004) Plant Physiology, $3^{\text {rd }}$ ed., Sinauer Associates Inc., Massachusetts.

Villagra PE, Cavagnaro JB (2006) Water stress effects on the seedling growth of Prosopis argentina and Prosopis alpataco. J. Arid Environ. 64: 390-400.

Walter A, Schurr U (2005) Dynamics of Leaf and Root Growth: Endogenous Control versus Environmental Impact. Ann. Bot. 95: 891-900. 